\title{
Sustaining Academic Progress Through Objective Evaluation Of Research In Nigeria
}

Donatus O. Owuamanam, University of Ado-Ekiti, Nigeria Theresa O. Owuamanam, University of Ado-Ekiti, Nigeria

\begin{abstract}
There has been serious disagreement regarding how best to objectively evaluate the research competence of university teachers to determine their suitability for promotion from one level to another. Different approaches are adopted by Nigerian Universities to ensure comparability of output of different people being considered for advancement. Doubt has been raised among teachers regarding the adequacy and objectivity of the criteria adopted in the evaluation process. A system of assigning points to every aspect of job output including research has been designed in the University of Ado-Ekiti, Nigeria and it is being tested for adoption in evaluating employees' output. Issues and questions have been raised about the adequacy of the system for evaluation purpose. This paper presents the point system of evaluation and clarifies some issues that have been raised about the system.
\end{abstract}

Keywords: Academic Progress, Research Evaluation

\section{INTRODUCTION}

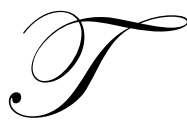

eaching in the University system is unique and distinct from other fields of work in Nigeria including teaching at other levels. In the University, assessment of productivity is based mainly on research and publications rather than teaching competence alone. Consequently, advancement on the job depends mainly on the individual's research output. There has been serious disagreement regarding how best to objectively evaluate the competence of an individual wishing to be promoted from one level to another. Different approaches have been adopted by individual Universities to ensure comparability of the output of different people being assessed for employment or promotion to the same cadre. Among these are the numbers of publications in reputable journals or by reputable publishers, assessment of publications by experts in the candidate's discipline, and assessment of the practical utility of the individual's research product. In spite of these, there is still doubt raised regarding the adequacy and objectivity of these criteria in deciding how competent the individual is in research.

In 2006, the University of Ado-Ekiti, Nigeria set up a committee to review the existing criteria for employment and promotions and make recommendation to the University's Appointments and Promotions Board. It was expected that such criteria could be found useful by other Universities in Nigeria and other parts of the world for employment and promotion purposes. The Committee gathered information on the existing practices in six Nigerian Universities and the University of Cape Coast, Ghana and came up with a system of assigning points to every aspect of an individual's output. The report is being tested to determine its suitability and usability. Issues and questions have been raised which need some answers and clarifications. This paper discusses the point system of assessment, clarifies some issues, and answers some questions that have arisen from the report.

\section{GENERAL GUIDELINE FOR EMPLOYMENT AND PROMOTION}

The following guidelines are adopted for advancement along the stages of promotion in academic career. 
- $\quad$ A candidate is to spend a minimum of three years at each level before he or she can be qualified for promotion.

- In general, all University teachers are required to hold a doctorate degree or evidence of registration and steady progress on a doctorate programme to qualify for promotion up to the grade of a Lecturer I. Candidates who do not hold a doctorate degree cannot be promoted beyond Lecturer I.

- Assessment of the candidates' research by experts in their discipline who are not members of their University is required for promotion to positions of a Senior Lecturer and above. At least one positive report is required for promotion to a Senior Lecturer and two for movement to a Reader or Professor. There must be evidence of continuing research productivity through publications.

- $\quad$ Besides setting a minimum score an individual must get on each criterion namely teaching, publications and service, there is a maximum score that a candidate can draw from each criterion to make up the total score required for promotion at each level. This is done to ensure that candidates being promoted must be good in all the criteria. For example, a competent researcher is expected to be good in teaching and service.

- $\quad$ From the grade of Lecturer 1, a candidate for promotion is required to publish a proportion of his research offshore. Offshore publications are those made outside Nigeria. The question that has been raised about this is if publication media based outside Nigeria are superior to those based in Nigeria. It is not suggested that journals or publishers based in Nigeria are inferior to international ones. The intention rather is, to encourage teachers to make their work known outside Nigeria.

- In order to merit promotion from Readership to Professorship position, $75 \%$ of all publications must be in print that is published and not merely accepted for publication.

- $\quad$ As candidates prepare to move from Senior Lecturer to Reader or Professor, more emphasis is placed on research and publications. The scores required on research for promotion greatly increases from this level. A candidate is therefore required to draw a greater proportion of the scores required for promotion from publications. Also because the emphasis on publications is the same for both levels, there is a sharp rise between Senior Lecturer and Reader and a leveling up between Reader and Professor.

\section{LEVELS OF CAREER ADVANCEMENT}

Universities in Nigeria have the following levels through which teachers pass in their teaching career. The scores required to pass from one level to another in the point system of evaluation are indicated at the relevant level in this paper.

\section{Graduate Assistant}

These are promising first-degree holders with a minimum of second-class honours upper division. They are expected to move to the next level within three years by obtaining a masters degree or have their appointment terminated. Currently the University of Ado-Ekiti no longer employs staff of this cadre. Individuals can therefore be employed as assistant lecturers if they possess a master's degree and show promise for research and teaching.

\section{Assistant Lecturer to Lecturer II}

Holders of a doctorate degree are employed as Lecturers II. However, Assistant Lecturers can be promoted to the grade of Lecturers II if they have master's degree. Such candidates shall be required to score a minimum of 4 points on research and publications 2 points on teaching, 2 points on public service and an overall total score of 22 points to qualify for promotion to a Lecturer II.

\section{Lecturer II to Lecturer I}

To qualify for promotion from Lecturer II to Lecturer I a candidate must have a Ph.D or show evidence of steady progress on the Ph.D programme. Such candidate must score a minimum of 18 points on teaching, 12 points on publications and an overall score of 34 points. 


\section{Lecturer I to Senior Lecturer}

To be promoted from Lecturer I to Senior Lecturer, the staff must obtain a minimum of 22 points on teaching and 16 points on research, four points which is $10 \%$ of the score on publications must be international (offshore) publications. In addition, the candidates publications shall be assessed by an expert in the relevant field who must be a Professor.

\section{Senior Lecturer to Reader}

A candidate for Readership position shall score not lower than 13 points on teaching, 36 points on publications and an overall total score of not lower than 63 points. Eight points which is $20 \%$ of the scores required on publication must be from offshore or international publications. In addition, $75 \%$ of all publications must be in print and at least two positive reports from external assessors are required.

\section{Readership to Professorship}

An academic staff with a minimum of 3 years teaching experience as a Reader may be promoted to the rank of a Professor, provided there is continuing productivity in research evidenced by substantial scholarly publications, The candidate must score not be lower than 47 points on publications, $12(30 \%)$ of which must be derived from offshore papers. The candidates should not score lower than 7 points in teaching and an overall total score not lower than 70 points.

A summary of the points required for each level is presented on Table I

Table 1: Relative Scores on the Criteria for Employment and Promotion

\begin{tabular}{|c|c|c|c|c|c|c|c|c|c|c|c|}
\hline \multirow[t]{2}{*}{ Criteria } & \multirow[t]{2}{*}{$\begin{array}{l}\text { Graduate } \\
\text { Assistant }\end{array}$} & \multicolumn{2}{|c|}{$\begin{array}{l}\text { Assistant Lect. } \\
\text { to Lecturer II }\end{array}$} & \multicolumn{2}{|c|}{$\begin{array}{c}\text { Lecturer II to } \\
\text { Lect. I }\end{array}$} & \multicolumn{2}{|c|}{$\begin{array}{l}\text { Lecturer I to } \\
\text { Sen. Lecturer }\end{array}$} & \multicolumn{2}{|c|}{$\begin{array}{c}\text { Sen. Lecturer } \\
\text { to Reader }\end{array}$} & \multicolumn{2}{|c|}{$\begin{array}{l}\text { Reader to } \\
\text { Professor }\end{array}$} \\
\hline & & Min & Max & Min & Max & Min & Max & Min & Max & Min & Max \\
\hline Qualification & & 5 & 5 & 10 & 7 & 10 & 10 & 10 & 10 & 10 & 10 \\
\hline Teaching & & 14 & 11 & 20 & 18 & 23 & 22 & 14 & 13 & 13 & 7 \\
\hline Service & & 3 & 2 & 3 & 1 & 5 & 3 & 6 & 4 & 7 & 5 \\
\hline Publications & & 6 & 4 & 12 & 8 & 24 & 16 & 54 & 36 & 66 & 47 \\
\hline Total & & 28 & 22 & 45 & 34 & 62 & 51 & 84 & 63 & 90 & 70 \\
\hline Pass Mark & & \multicolumn{2}{|c|}{22} & \multicolumn{2}{|c|}{34} & \multicolumn{2}{|c|}{$\frac{1}{51}$} & \multicolumn{2}{|c|}{63} & \multicolumn{2}{|c|}{70} \\
\hline
\end{tabular}

Source: University of Ado-Ekiti Appointments and Promotions Board Paper No. 2008/26.

\section{THE POINT SYSTEM OF EVALUATION}

Promotion is through the point system of evaluation. For the purpose of promotion, an academic staff is scored on the following criteria as required of University teachers namely, research and publications, teaching, service and academic qualifications. This paper focuses on the point system of evaluating research and publications. Publications are classified into four major groups, namely books/monographs, chapters in books, papers in learned journals and published conference proceedings/technical reports. Generally books score highest while conference proceedings and technical reports score least. The quality of a book is judged by the reputation or quality of its publisher. Based on this, four categories of publications are recognized for assessment. These are:

- $\quad$ Top university texts. These are books published by recognized overseas publishers.

- $\quad$ Standard university texts. These are books published by recognized overseas or Nigerian publishers.

- $\quad$ Other University texts. These are books written for university courses but published by local publishers.

- Non-University texts of academic value. These are non-university books published by recognized publishers, which are acceptable to the Appointment and Promotions Board. 
- A self-made book or monograph is not assessed or scored. A list of recognized publishers is available in the University library.

Books and book chapters are scored according to the category to which their publishers belong, books and book chapters in category (i) scoring highest and those in category (iv) scoring least.

Journal articles score lower than books. Journal articles are scored on the basis of the status of publication (published or accepted), place of publication, and number of authors. Articles already published are given more weight than those only accepted for publication. Journals based outside the country, outside the candidates' University, Faculty or Department are scored higher than those based within. Articles written by a single author are scored higher than those jointly written.

While articles published outside the candidates institution, faculty or department of affiliation are not necessarily judged superior to those published in journals based inside, blind review is thought to be more assured when the journal is based outside than when inside.

Six categories of journals are recognized for assessment and scoring. Scores are assigned differentially to the different categories.

- International (offshore) journals. These are journals based outside Nigeria

- $\quad$ Reputable journals based outside the University. These are society, association, professional and multidisciplinary journals and journals based in other Universities which enjoy wide acceptability within the academic circle.

- Journals based in the University but outside the candidate's faculty.

- $\quad$ Faculty journals. These are journals based in the candidate's faculty.

- Journals based in the candidates department.

- $\quad$ Conference proceedings.

Articles in magazines, newspapers, bulletins, student journals and company reports are not acceptable as academic publications.

A combination of these criteria generate different set of scores for books, book chapters, and journal articles as summarized and presented in Tables 2,3,4 and 5 .

Table 2: Scoring for Books

\begin{tabular}{|l|c|c|c|c|}
\hline Type of Book & Max. Point & Sole Author & Joint Authors & $\begin{array}{c}\text { Multiple } \\
\text { Authors }\end{array}$ \\
\hline Top University Texts & 5 & 5 & 3 & 2 \\
\hline Standard University Texts & 3 & 3 & 2 & 1 \\
\hline Other University Texts & 1.5 & 1.5 & 1 & 0.5 \\
\hline Non-University Texts & 1.0 & 1.0 & 0.5 & 0.5 \\
\hline
\end{tabular}

Table 3: Scoring for Chapters in Books

\begin{tabular}{|l|c|c|c|c|}
\hline Type of Book & Max. point & Sole Author & Joint Authors & $\begin{array}{c}\text { Multiple } \\
\text { Authors }\end{array}$ \\
\hline Top University Text & 3 & 3 & 2 & 1 \\
\hline Standard University Text & 1.5 & 1.5 & 1 & 0.5 \\
\hline Other University Text & 1 & 1 & 0.5 & 0.5 \\
\hline Non-University Text & 0.5 & 0.5 & 0.5 & 0.5 \\
\hline
\end{tabular}


Table 4: Scoring for Published Articles in Learned Journals

\begin{tabular}{|c|c|c|c|c|}
\hline Type of Book & $\begin{array}{l}\text { Max. } \\
\text { Point }\end{array}$ & $\begin{array}{c}\text { Sole } \\
\text { Authorship }\end{array}$ & $\begin{array}{c}\text { Joint } \\
\text { Authorship }\end{array}$ & $\begin{array}{c}\text { Multiple } \\
\text { Authorship }\end{array}$ \\
\hline International (Off-shore) Journal & 4 & 4 & 3 & 2 \\
\hline Standard Journal based outside the University & 3 & 3 & 2 & 1 \\
\hline Journal outside the Candidate's Faculty & 2 & 2 & 1 & 0.5 \\
\hline Journal inside the Candidate's Faculty. & 1.5 & 1.5 & 1 & 0.5 \\
\hline Journal in the Candidate's Department & 1 & 1 & 0.5 & 0.5 \\
\hline Conference Proceedings/Technical Reports & 1 & 1 & 0.5 & 0.5 \\
\hline
\end{tabular}

Table 5: Scoring for Published Articles in Learned Journals

\begin{tabular}{|c|c|c|c|c|}
\hline Type of Book & $\begin{array}{l}\text { Max. } \\
\text { point }\end{array}$ & $\begin{array}{c}\text { Sole } \\
\text { Authorship } \\
\end{array}$ & $\begin{array}{c}\text { Joint } \\
\text { Authorship } \\
\end{array}$ & $\begin{array}{c}\text { Multiple } \\
\text { Authorship }\end{array}$ \\
\hline International (Off-shore) Journal & 2.5 & 2.5 & 1.5 & 1 \\
\hline Standard Journal based outside the University & 2 & 2 & 1 & 0.5 \\
\hline Journal outside the Candidate's Faculty & 1.5 & 1.5 & 1 & 0.5 \\
\hline Journal inside the Candidate's Faculty. & 1 & 1 & 0.5 & 0.5 \\
\hline Journal in the Candidate's Department & 0.5 & 0.5 & 0.5 & 0.5 \\
\hline Conference Proceedings/Technical Reports & 0.5 & 0.5 & 0.5 & 0.5 \\
\hline
\end{tabular}

\section{CONCLUSION}

The points should serve as a guide to the assessor in deciding the maximum point to award in each case. The actual score to be awarded depends on the assessor's judgment of the quality of the paper. The point system provides an objective process of evaluation. Inter-rater variability is minimal. It gives an opportunity for a candidate to score himself to determine his suitability for promotion. 
NOTES 